\title{
EVALUASI TINGKAT KELELAHAN DITINJAU DARI SEGI ERGONOMI PADA TENAGA KERJA BONGKAR MUAT BARANG DI PELABUHAN KOTA SORONG
}

\author{
Sanny Hahury \\ Program Studi Teknik Industri \\ Fakultas Teknik Universitas Muhammadiyah Sorong \\ e-mail : $\underline{\text { sanny0577.sh@gmail.com }}$
}

Diterima: 28 April 2017. Dipublikasikan: 1 Juni 2017

\begin{abstract}
ABSTRAK
Seorang pekerja pada suatu lingkungan kerja tentu menginginkan pekerjaan yang dapat dikerjakan dengan tenaga seminimal mungkin, akan tetapi memberikan hasil yang maksimal. Akan tetapi sering hal tersebut tidak tercapai karena beberapa faktor yang mempengaruhi pekerjaan tersebut seperti kondisi lingkungan kerja, metode kerja dan postur seorang pekerja dalam melakukan pekerjaannya. Operator yang bekerja mengangkat dan menyusun barang pada bagian pengangkatan barang sering mengalami kondisi yang cepat lelah dan adanya keluhan sakit dan nyeri pada tulang belakang dan kaki terutama pada betis. Penelitian ini dilakukan pada Pelabuhan Kota Sorong yang bertujuan untuk mengetahui tingkat kelelahan pada tenaga kerja bongkar muat barang pada saat memindahkan barang. Dalam penelitian ini penulis menggunakan Metode Rula yaitu metode pengamatan bentuk postur tubuh pada saat memindahkan barang dimana pengukuran tingkat kelelahannya ditentukan dari pemberian skor. Adapun teknik pengolahan data yang penulis gunakan dalam penelitian ini adalah mengamati bentuk tubuh saat bekerja, mengukur bentuk postur tubuh, pemberian skor, menentukan tindakan tingkat kelelahan. Setelah penulis melakukan penelitian pada Tenaga Kerja Bongkar Muat Barang di Pelabuhan Kota Sorong dan memperoleh data-data yang dibutuhkan, maka penulis melakukan pengukuran dan analisa data dan didapatkan hasil bahwa tingkat kelelahan pada para tenaga kerja bongkar muat barang di Pelabuhan Kota Sorong beresiko tinggi dengan rata-rata tingkat kelelahan berada pada level 7+ dan membutuhkan tindakan perbaikan.
\end{abstract}

Kata Kunci : Rula, Penentuan Skor, Tindakan Perbaikan

\section{Latar Belakang}

Seorang pekerja pada suatu lingkungan kerja tentu menginginkan pekerjaan yang dapat dikerjakan dengan tenaga seminimal mungkin, akan tetapi memberikan hasil yang maksimal. Akan tetapi sering hal tersebut tidak tercapai karena beberapa faktor yang mempengaruhi pekerjaan tersebut seperti kondisi lingkungan kerja, metode kerja dan postur seorang pekerja dalam melakukan pekerjaannya.

Pelabuhan kota Sorong merupakan satu satunya tempat keluar masuknya kapal besar baik kapal penumpang maupun kapal barang. Pada kapal barang di pelabuhan kota sorong pemindahan barang dari container ke mobil truck masih menggunakan tenaga manusia. Bagi operator yang bekerja mengangkat dan menyusun barang pada bagian pengangkatan barang pekerjaan ini menyebabkan kondisi operator yang menjadi cepat lelah dan adanya keluhan sakit dan nyeri pada tulang belakang dan kaki terutama pada betis.

Penelitian ini dilakukan untuk mengetahui penyebab operator cepat menjadi lelah dengan meneliti pengaruh variabel yang berhubungan langsung terhadap pengangkatan dan penurunan barang dan mengetahui pengaruh antara penilaian postur kerja dengan variabel berat beban kerja dan frekuensinya.

Dari uraian di atas maka penulis ini menelitinya dengan judul "EVALUASI TINGKAT KELELAHAN DITINJAU DARI SEGI ERGONOMI PADA TENAGA KERJA BONGKAR MUAT 
BARANG DI PELABUHAN KOTA SORONG".

\section{Landasan Teori}

Ergonomi merupakan suatu cabang ilmu yang sistematis untuk memanfaatkan informasi-informasi mengenai sifat, kemampuan dan keterbatasan manusia untuk merancang suatu sistem kerja, sehingga dapat hidup dan bekerja dengan baik yang akhirnya akan mencapai tujuan yang diinginkan melalui pekerjaan tersebut dengan efektif, nyaman, aman, sehat dan efisien.

Tujuan ergonomi adalah untuk meningkatkan produktivitas tenaga kerja pada suatu perusahaan atau organisasi. Hal ini dapat tercapai apabila terjadi kesesuaian antar pekerja dengan pekerjaannya. Banyak yang menyimpulkan bahwa tenaga kerja harus dimotivasi dan kebutuhannya terpenuhi. Dengan demikian akan menurunkan jumlah tenaga kerja yang tidak masuk kerja. Namun pendekatan ergonomi mencoba mencapai kebaikan antara pekerja dan pimpinan perusahaan. Hal ini dapat dicapai dengan memperhatikan empat tujuan utama, antara lain :

1. Memaksimalkan efisiensi tenaga kerja
2. Memperhatikan kesehatan dan keselamatan kerja

3. Menganjurkan agar bekerja aman, nyaman dan bersemangat

4. Memaksimalkan performansi kerja yang meyakinkan

Postur tubuh adalah posisi tubuh manusia secara keseluruhan. Pada saat bekerja posisi tubuh tiap pekerja berbeda yaitu postur kerja yang merupakan posisi tubuh pada saat pekerja melakukan aktivitasnya.Tubuh adalah keseluruhan jasad manusia yang kelihatan dari ujung rambut sampai ujung kaki. Postur tubuh adalah bentuk tubuh atau sikap badan yang terlibat dari ujung rambut sampai ujung kaki.

\section{Flow Chart Peneelitian}

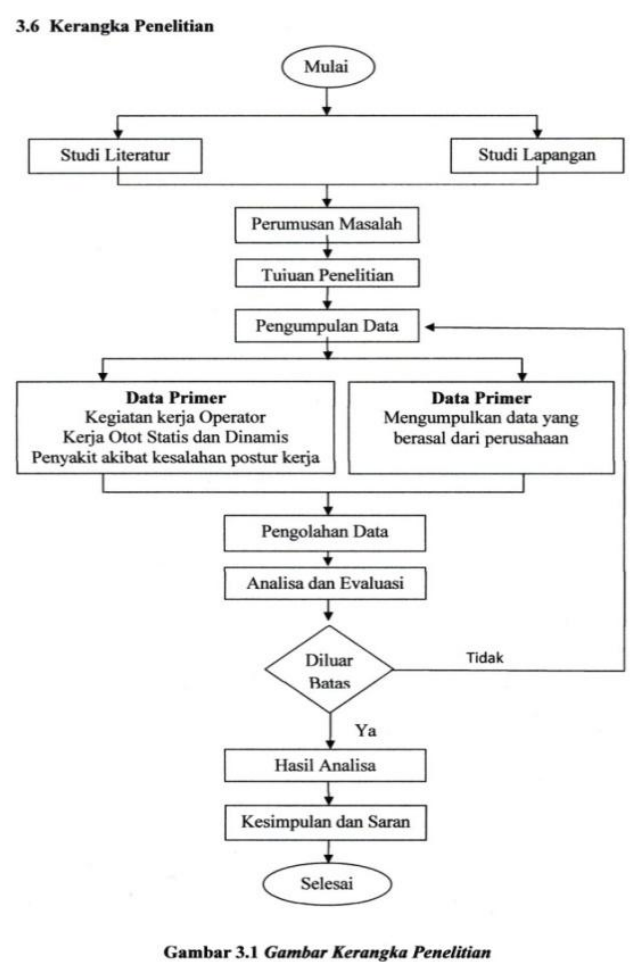




\section{Hasil Penelitian}

\section{Gambaran Umum Pelabuhan Kota} Sorong

Pelabuhan Sorong adalah salah satu pintu gerbang perhubungan laut di Propinsi Papua Barat dan Papua yang melayani arus penumpang dan barang yang berasal dari Sorong ke Sorong Selatan, Manokwari, Raja Ampat, Wondama, Serui, Nabire, Fak-Fak, Kaimana, Bintuni, Biak, Jayapura, Maluku, Sulawesi dan Jawa ataupun sebaliknya

Pelabuhan Sorong memiliki tipe pelabuhan kelas Utama atau kelas Nasional. Ditinjau dari segi teknis pelabuhan Sorong adalah termasuk pelabuhan alam, karena tidak perlu dibangun breakwater untuk menjamin keamanan kapal dalam melakukan bongkar muat.

\section{Pengolahan Data}
a. Kegiatan Menjangkau Barang
b. Kegiatan mengangkat Barang
c. Kegiatan membawa Barang
d. Kegiatan meletakkan Barang

\section{Pemberian Skor}

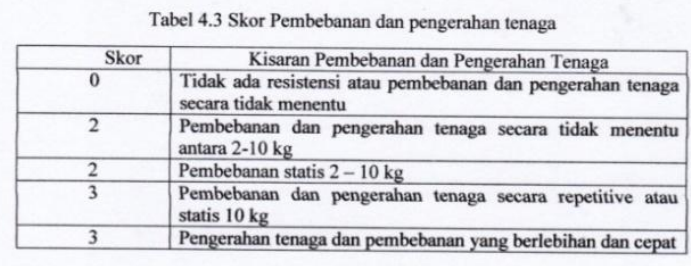

Gambar 4.1 Kegiatan Menjangkau barang

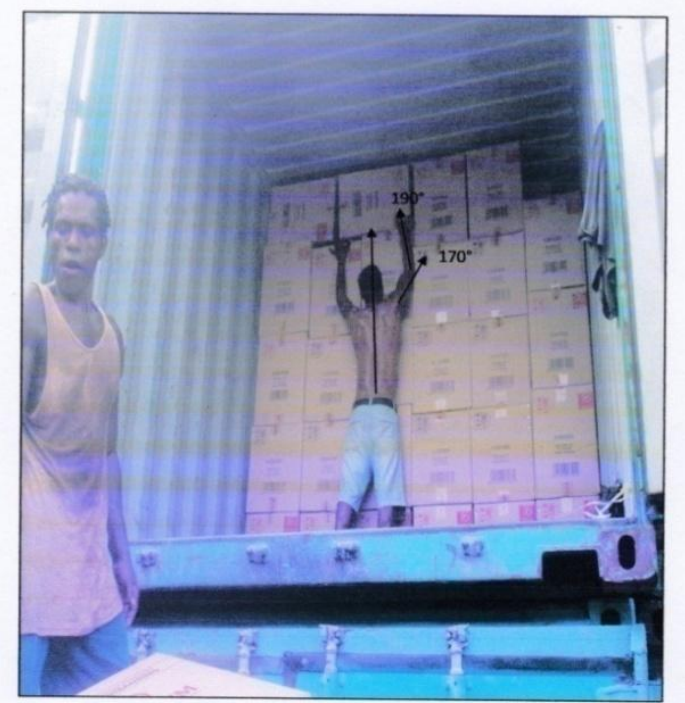

Tabel 4.4 Skor grup A Kegiatan Menjangkau Barang

\begin{tabular}{|c|c|c|c|c|c|c|c|c|c|}
\hline \multirow{4}{*}{$\begin{array}{c}\text { Lengan } \\
\text { atas }\end{array}$} & \multirow{4}{*}{$\begin{array}{l}\text { Lengan } \\
\text { bawah }\end{array}$} & \multicolumn{8}{|c|}{ Pergelangan Tangan } \\
\hline & & \multicolumn{2}{|c|}{1} & \multicolumn{2}{|c|}{2} & \multicolumn{2}{|c|}{3} & \multicolumn{2}{|c|}{4} \\
\hline & & \multicolumn{2}{|c|}{$\begin{array}{c}\text { Pergelangan } \\
\text { Tangan } \\
\text { Memuntir }\end{array}$} & \multicolumn{2}{|c|}{$\begin{array}{c}\text { Pergelangan } \\
\text { Tangan } \\
\text { Memuntir }\end{array}$} & \multicolumn{2}{|c|}{$\begin{array}{c}\text { Pergelangan } \\
\text { Tangan } \\
\text { Memuntir }\end{array}$} & \multicolumn{2}{|c|}{$\begin{array}{c}\text { Pergelangan } \\
\text { Tangan } \\
\text { Memuntir }\end{array}$} \\
\hline & & 1 & 2 & 1 & 2 & 1 & 2 & 1 & \\
\hline \multirow{3}{*}{1} & 1 & 1 & 2 & 2 & 2 & 2 & 3 & 3 & 3 \\
\hline & 2 & 2 & 2 & 2 & 2 & 3 & 3 & 3 & 3 \\
\hline & 3 & 2 & 3 & 3 & 3 & 3 & 3 & 4 & 4 \\
\hline \multirow{3}{*}{2} & 1 & 2 & 3 & 3 & 3 & 3 & 4 & 4 & 4 \\
\hline & 2 & 3 & 3 & 3 & 3 & 3 & 4 & 4 & 5 \\
\hline & 3 & 3 & 4 & 4 & 4 & 4 & 4 & 5 & 5 \\
\hline \multirow{3}{*}{3} & 1 & 3 & 3 & 4 & 4 & 4 & 4 & 5 & 5 \\
\hline & 2 & 4 & 4 & 4 & 4 & 4 & 4 & 5 & 5 \\
\hline & 3 & 4 & 4 & 4 & 4 & 4 & 5 & 5 & 5 \\
\hline \multirow{3}{*}{4} & 1 & 4 & 4 & 4 & 4 & 4 & 5 & 5 & 5 \\
\hline & 2 & 4 & 4 & 4 & 4 & 4 & 5 & 5 & 5 \\
\hline & 3 & 4 & 4 & 4 & 5 & 5 & 5 & 6 & 6 \\
\hline \multirow{3}{*}{5} & 1 & 5 & 5 & 5 & 5 & 5 & 6 & 6 & 7 \\
\hline & 2 & 5 & 6 & 6 & 6 & 6 & 7 & 7 & 7 \\
\hline & 3 & 6 & 6 & 6 & 7 & 7 & 7 & 7 & 8 \\
\hline \multirow{3}{*}{6} & 1 & 7 & 7 & 7 & 7 & 7 & 8 & 8 & 9 \\
\hline & 2 & 8 & 8 & 8 & 8 & 8 & 9 & 9 & 9 \\
\hline & 3 & 9 & 9 & 9 & 9 & 9 & 9 & 9 & 9 \\
\hline
\end{tabular}

Tabel 4.5 Skor grup B Kegiatan Menjangkau Barang

\begin{tabular}{|c|c|c|c|c|c|c|c|c|c|c|c|c|}
\hline \multirow{4}{*}{ Leher } & \multicolumn{12}{|c|}{ Badan (Trunk) } \\
\hline & 1 & & & & 3 & & 4 & & 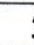 & & & 6 \\
\hline & $\mathrm{K}$ & & & & $\mathrm{Ka}$ & & $\mathrm{Ka}$ & & $\mathrm{K}$ & & & aki \\
\hline & 1 & 2 & 1 & 2 & 1 & 2 & 1 & 2 & & 2 & 1 & 2 \\
\hline 1 & 1 & 3 & 2 & 3 & 3 & 4 & 5 & 5 & 6 & 6 & 7 & 7 \\
\hline 2 & 2 & 3 & 2 & 3 & 4 & 5 & 5 & 5 & 6 & 7 & 7 & 7 \\
\hline 3 & 3 & 3 & 2 & 4 & 4 & 5 & 5 & 6 & 6 & 7 & 7 & 7 \\
\hline 4 & 5 & 5 & 5 & 6 & 6 & 7 & 7 & 7 & 7 & 7 & 8 & 8 \\
\hline 5 & 7 & 7 & 7 & 7 & 7 & 7 & 8 & 8 & 8 & 8 & 8 & 8 \\
\hline 6 & 8 & 8 & 8 & 8 & 8 & 8 & 8 & 9 & 9 & 9 & 9 & 9 \\
\hline
\end{tabular}

Tabel 4.6 Total skor group A dan B Kegiatan Menjangkau Barang

\begin{tabular}{|c|c|c|c|c|c|c|c|}
\hline \multirow{2}{*}{ Grup A } & \multicolumn{7}{|c|}{ Grup B } \\
\cline { 2 - 8 } & 1 & 2 & 3 & 4 & 5 & 6 & 7 \\
\hline 1 & 1 & 2 & 3 & 3 & 4 & 5 & 5 \\
\hline 2 & 2 & 2 & 3 & 4 & 4 & 5 & 5 \\
\hline 3 & 3 & 3 & 3 & 4 & 4 & 5 & 6 \\
\hline 4 & 3 & 3 & 3 & 4 & 5 & 6 & 6 \\
\hline 5 & 4 & 4 & 4 & 5 & 6 & 7 & 7 \\
\hline 6 & 4 & 4 & 5 & 6 & 6 & 7 & 7 \\
\hline 7 & 5 & 5 & 6 & 6 & 7 & 7 & 7 \\
\hline 8 & 5 & 5 & 6 & 7 & 7 & 7 & 7 \\
\hline
\end{tabular}

Total skor akhir untuk aktifitas mengangkat karton rokok adalah 8 
Tabel 4.7 Tingkat aksi yang diperlukan berdasarkan Grand skor

\begin{tabular}{|c|l|}
\hline Level & \multicolumn{1}{|c|}{ Tingkat Aksi dari RULA } \\
\hline 1 & $\begin{array}{l}\text { Apabila grand skor adalah } 1 \text { atau 2, tidak ada masalah dengan } \\
\text { postur tubuh selama bekerja }\end{array}$ \\
\hline 2 & $\begin{array}{l}\text { Apabila grand skor adalah 3 atau 4, diperlukan investigasi } \\
\text { lebih lanjut, mungkin diperlukan adanya perubahan untuk } \\
\text { perbaikan sikap kerja. }\end{array}$ \\
\hline 3 & $\begin{array}{l}\text { Apabila grand skor adalah 5 atau 6, diperlukan adanya } \\
\text { investigasi dan perbaikan segea. }\end{array}$ \\
\hline 4 & $\begin{array}{l}\text { Apabila grand skor adalah 7+, diperlukan adanya investigasi } \\
\text { dan perbaikan secepat mungkin. }\end{array}$ \\
\hline
\end{tabular}

Gambar 4.2 Kegiatan Mengangkat Barang

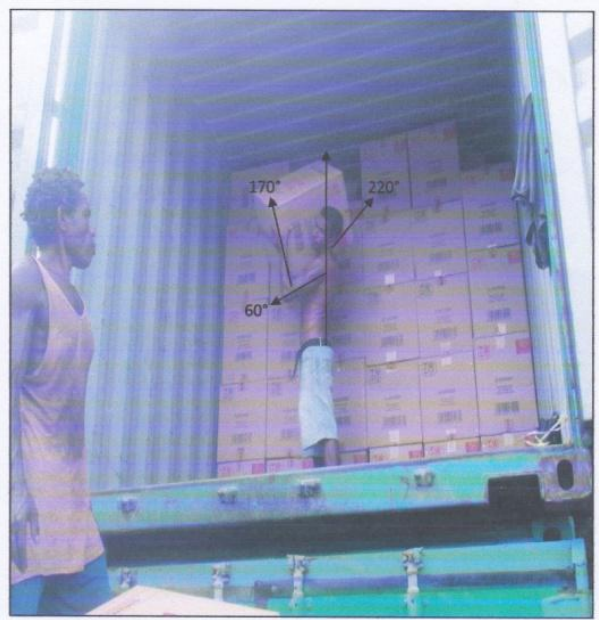

Tabel 4.8 Skor Grup A Kegiatan Mengangkat Barang

\begin{tabular}{|c|c|c|c|c|c|c|c|c|c|}
\hline \multirow{4}{*}{$\begin{array}{l}\text { Lengan } \\
\text { atas }\end{array}$} & \multirow{4}{*}{$\begin{array}{l}\text { Lengan } \\
\text { bawah }\end{array}$} & \multicolumn{8}{|c|}{ Pergelangan Tangan } \\
\hline & & \multicolumn{2}{|c|}{1} & \multicolumn{2}{|c|}{2} & \multicolumn{2}{|c|}{3} & \multicolumn{2}{|c|}{4} \\
\hline & & \multicolumn{2}{|c|}{$\begin{array}{c}\text { Pergelangan } \\
\text { Tangan } \\
\text { Memuntir }\end{array}$} & \multicolumn{2}{|c|}{$\begin{array}{c}\text { Pergelangan } \\
\text { Tangan } \\
\text { Memuntir }\end{array}$} & \multicolumn{2}{|c|}{$\begin{array}{c}\text { Pergelangan } \\
\text { Tangan } \\
\text { Memuntir }\end{array}$} & \multicolumn{2}{|c|}{$\begin{array}{c}\text { Pergelangan } \\
\text { Tangan } \\
\text { Memuntir }\end{array}$} \\
\hline & & 1 & 2 & 1 & 2 & 1 & 2 & 1 & \\
\hline \multirow{3}{*}{1} & 1 & 1 & 2 & 2 & 2 & 2 & 3 & 3 & 3 \\
\hline & 2 & 2 & 2 & 2 & 2 & 3 & 3 & 3 & 3 \\
\hline & 3 & 2 & 3 & 3 & 3 & 3 & 3 & 4 & 4 \\
\hline \multirow{3}{*}{2} & 1 & 2 & 3 & 3 & 3 & 3 & 4 & 4 & 4 \\
\hline & 2 & 3 & 3 & 3 & 3 & 3 & 4 & 4 & 5 \\
\hline & 3 & 3 & 4 & 4 & 4 & 4 & 4 & 5 & 5 \\
\hline \multirow{3}{*}{3} & 1 & 3 & 3 & 4 & 4 & 4 & 4 & 5 & 5 \\
\hline & 2 & 4 & 4 & 4 & 4 & 4 & 4 & 5 & 5 \\
\hline & 3 & 4 & 4 & 4 & 4 & 4 & 5 & 5 & 5 \\
\hline \multirow{3}{*}{4} & 1 & 4 & 4 & 4 & 4 & 4 & 5 & 5 & 5 \\
\hline & 2 & 4 & 4 & 4 & 4 & 4 & 5 & 5 & 5 \\
\hline & 3 & 4 & 4 & 4 & 5 & 5 & 5 & 6 & 6 \\
\hline \multirow{3}{*}{5} & 1 & 5 & 5 & 5 & 5 & 5 & 6 & 6 & 7 \\
\hline & 2 & 5 & 6 & 6 & 6 & 6 & 7 & 7 & 7 \\
\hline & 3 & 6 & 6 & 6 & 7 & 7 & 7 & 7 & 8 \\
\hline \multirow{3}{*}{6} & 1 & 7 & 7 & 7 & 7 & 7 & 8 & 8 & 9 \\
\hline & 2 & 8 & 8 & 8 & 8 & 8 & 9 & 9 & 9 \\
\hline & 3 & 9 & 9 & 9 & 9 & 9 & 9 & 9 & 9 \\
\hline
\end{tabular}

Tabel 4.9 Skor Grup B Kegiatan Mengangkat Barang

\begin{tabular}{|c|c|c|c|c|c|c|c|c|c|c|c|c|}
\hline \multirow[b]{4}{*}{ Leher } & \multicolumn{12}{|c|}{ Badan (Trunk) } \\
\hline & \multirow{2}{*}{\multicolumn{2}{|c|}{$\begin{array}{c}1 \\
\text { Kaki }\end{array}$}} & \multirow{2}{*}{\multicolumn{2}{|c|}{$\begin{array}{c}2 \\
\text { Kaki }\end{array}$}} & & & & & & & & \\
\hline & & & & & \multicolumn{2}{|c|}{ Kaki } & \multicolumn{2}{|c|}{ Kaki } & \multicolumn{2}{|c|}{ Kaki } & \multicolumn{2}{|c|}{ Kaki } \\
\hline & 1 & 2 & 1 & 2 & 1 & 2 & 1 & 2 & 1 & 2 & 1 & 2 \\
\hline 1 & 1 & 3 & 2 & 3 & 3 & 4 & 5 & 5 & 6 & 6 & 7 & 7 \\
\hline$\frac{1}{2}$ & $\frac{1}{2}$ & $\frac{3}{3}$ & 2 & $\frac{3}{3}$ & $\frac{3}{4}$ & $\frac{4}{5}$ & $\frac{5}{5}$ & $\frac{3}{5}$ & $\frac{0}{6}$ & $\frac{0}{7}$ & $\frac{1}{7}$ & \\
\hline 3 & 3 & 3 & 2 & 4 & 4 & 5 & 5 & 6 & 6 & 7 & 7 & 7 \\
\hline 4 & 5 & 5 & 5 & 6 & 6 & 7 & 7 & 7 & 7 & 7 & 8 & 8 \\
\hline 5 & 7 & 7 & 7 & 7 & 7 & 7 & 8 & 8 & $\frac{1}{8}$ & 8 & 8 & 8 \\
\hline 6 & 8 & 8 & 8 & 8 & 8 & 8 & 8 & 9 & 9 & 9 & 9 & 9 \\
\hline
\end{tabular}

3. Skor aktifitas

Aktifitas dilakukan tidak berulang - ulang dan beban $>10 \mathrm{~kg}$ dengan skor

4. Total skor group $B$ adalah $5+3=8$

Tabel 4.10 Total skor group A dan B Kegiatan Mengangkat Barang

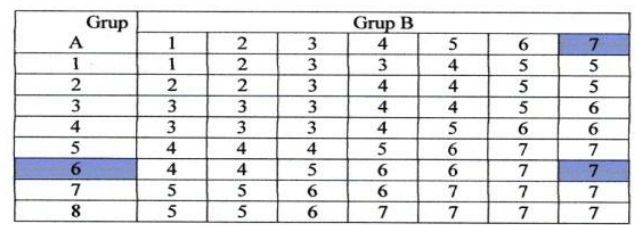

Skor akhir untuk aktifitas mengangkat karton rokok adalah $=7$

Tabel 4.11 Tingkat aksi yang diperlukan berdasarkan Grand skor

\begin{tabular}{|c|l|}
\hline Level & \multicolumn{1}{|c|}{ Tingkat Aksi dari RULA } \\
\hline 1 & $\begin{array}{l}\text { Apabila grand skor adalah 1 atau 2, tidak ada masalah dengan } \\
\text { postur tubuh selama bekerja }\end{array}$ \\
\hline 2 & $\begin{array}{l}\text { Apabila grand skor adalah 3 atau 4, diperlukan investigasi } \\
\text { lebih lanjut, mungkin diperlukan adanya perubahan untuk } \\
\text { perbaikan sikap kerja. }\end{array}$ \\
\hline 3 & $\begin{array}{l}\text { Apabila grand skor adalah 5 atau 6, diperlukan adanya } \\
\text { investigasi dan perbaikan segea. }\end{array}$ \\
\hline 4 & $\begin{array}{l}\text { Apabila grand skor adalah 7+, diperlukan adanya investigasi } \\
\text { dan perbaikan secepat mungkin. }\end{array}$ \\
\hline
\end{tabular}

Gambar 4.3 Kegiatan Meletakkan Barang

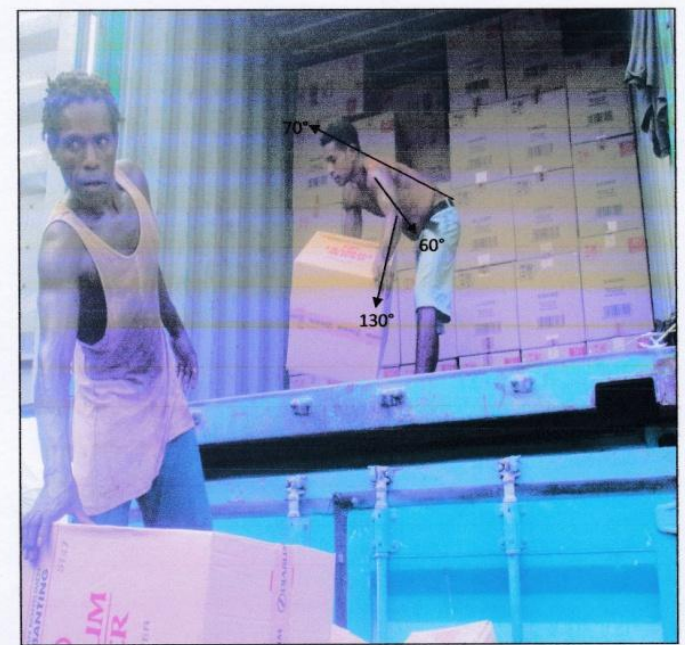


Tabel 4.12 Skor Grup A Kegiatan Meletakkan Barang

\begin{tabular}{|c|c|c|c|c|c|c|c|c|c|}
\hline \multirow{4}{*}{$\begin{array}{c}\text { Lengan } \\
\text { atas }\end{array}$} & \multirow{4}{*}{$\begin{array}{l}\text { Lengan } \\
\text { bawah }\end{array}$} & \multicolumn{8}{|c|}{ Pergelangan Tangan } \\
\hline & & \multicolumn{2}{|c|}{1} & \multicolumn{2}{|c|}{2} & \multicolumn{2}{|c|}{3} & \multicolumn{2}{|c|}{4} \\
\hline & & \multicolumn{2}{|c|}{$\begin{array}{l}\text { Pergelangan } \\
\text { Tangan } \\
\text { Memuntir }\end{array}$} & \multicolumn{2}{|c|}{$\begin{array}{l}\text { Pergelangan } \\
\text { Tangan } \\
\text { Memuntir }\end{array}$} & \multicolumn{2}{|c|}{$\begin{array}{l}\text { Pergelangan } \\
\text { Tangan } \\
\text { Memuntir }\end{array}$} & \multicolumn{2}{|c|}{$\begin{array}{c}\text { Pergelangan } \\
\text { Tangan } \\
\text { Memuntir }\end{array}$} \\
\hline & & 1 & 2 & 1 & 2 & 1 & 2 & 1 & \\
\hline \multirow{3}{*}{1} & 1 & 1 & 2 & 2 & 2 & 2 & 3 & 3 & 3 \\
\hline & 2 & 2 & 2 & 2 & 2 & 3 & 3 & 3 & 3 \\
\hline & 3 & 2 & 3 & 3 & 3 & 3 & 3 & 4 & 4 \\
\hline \multirow{3}{*}{2} & 1 & 2 & 3 & 3 & 3 & 3 & 4 & 4 & 4 \\
\hline & 2 & 3 & 3 & 3 & 3 & 3 & 4 & 4 & 5 \\
\hline & 3 & 3 & 4 & 4 & 4 & 4 & 4 & 5 & 5 \\
\hline \multirow{3}{*}{3} & 1 & 3 & 3 & 4 & 4 & 4 & 4 & 5 & 5 \\
\hline & 2 & 4 & 4 & 4 & 4 & 4 & 4 & 5 & 5 \\
\hline & 3 & 4 & 4 & 4 & 4 & 4 & 5 & 5 & 5 \\
\hline \multirow{3}{*}{4} & 1 & 4 & 4 & 4 & 4 & 4 & 5 & 5 & 5 \\
\hline & 2 & 4 & 4 & 4 & 4 & 4 & 5 & 5 & 5 \\
\hline & 3 & 4 & 4 & 4 & 5 & 5 & 5 & 6 & 6 \\
\hline \multirow{3}{*}{5} & 1 & 5 & 5 & 5 & 5 & 5 & 6 & 6 & 7 \\
\hline & 2 & 5 & 6 & 6 & 6 & 6 & 7 & 7 & 7 \\
\hline & 3 & 6 & 6 & 6 & 7 & 7 & 7 & 7 & 8 \\
\hline \multirow{3}{*}{6} & 1 & 7 & 7 & 7 & 7 & 7 & 8 & 8 & 9 \\
\hline & 2 & 8 & 8 & 8 & 8 & 8 & 9 & 9 & 9 \\
\hline & 3 & 9 & 9 & 9 & 9 & 9 & 9 & 9 & 9 \\
\hline
\end{tabular}

Tabel 4.13 Skor Grup B Kegiatan Meletakkan Barang

\begin{tabular}{|c|c|c|c|c|c|c|c|c|c|c|c|c|}
\hline \multirow[b]{4}{*}{ Leher } & \multicolumn{12}{|c|}{ Badan (Trunk) } \\
\hline & \multicolumn{2}{|c|}{1} & \multicolumn{2}{|c|}{2} & \multirow{2}{*}{\multicolumn{2}{|c|}{$\frac{3}{K a k i}$}} & \multirow{2}{*}{\multicolumn{2}{|c|}{$\begin{array}{c}4 \\
\text { Kaki }\end{array}$}} & \multirow{2}{*}{\multicolumn{2}{|c|}{$\begin{array}{c}5 \\
\text { Kaki }\end{array}$}} & & \\
\hline & \multicolumn{2}{|c|}{ Kaki } & \multicolumn{2}{|c|}{ Kaki } & & & & & & & \multicolumn{2}{|c|}{ Kaki } \\
\hline & 1 & 2 & 1 & 2 & 1 & 2 & 1 & 2 & 1 & 2 & 1 & 2 \\
\hline 1 & 1 & 3 & 2 & 3 & 3 & 4 & 5 & 5 & 6 & 6 & 7 & 7 \\
\hline 2 & 2 & 3 & 2 & 3 & 4 & 5 & 5 & 5 & 6 & 7 & 7 & 7 \\
\hline 3 & 3 & 3 & 2 & 4 & 4 & 5 & 5 & 6 & 6 & 7 & 7 & 7 \\
\hline 4 & 5 & 5 & 5 & 6 & 6 & 7 & 7 & 7 & 7 & 7 & 8 & 8 \\
\hline 5 & 7 & 7 & 7 & 7 & 7 & 7 & 8 & 8 & 8 & 8 & 8 & 8 \\
\hline 6 & 8 & 8 & 8 & 8 & 8 & 8 & 8 & 9 & 9 & 9 & 9 & 9 \\
\hline
\end{tabular}

Tabel 4.14 Total Skor group A dan B Kegiatan Meletakkan Barang

\begin{tabular}{|c|c|c|c|c|c|c|c|}
\hline \multirow{2}{*}{ Grup A } & \multicolumn{7}{|c|}{ Grup B } \\
\cline { 2 - 8 } & 1 & 2 & 3 & 4 & 5 & 6 & $7+$ \\
\hline 1 & 1 & 2 & 3 & 3 & 4 & 5 & 5 \\
\hline 2 & 2 & 2 & 3 & 4 & 4 & 5 & 5 \\
\hline 3 & 3 & 3 & 3 & 4 & 4 & 5 & 6 \\
\hline 4 & 3 & 3 & 3 & 4 & 5 & 6 & 6 \\
\hline 5 & 4 & 4 & 4 & 5 & 6 & 7 & 7 \\
\hline 6 & 4 & 4 & 5 & 6 & 6 & 7 & 7 \\
\hline 7 & 5 & 5 & 6 & 6 & 7 & 7 & 7 \\
\hline 8 & 5 & 5 & 6 & 7 & 7 & 7 & 7 \\
\hline
\end{tabular}

Total skor akhir pengangkatan karton rokok adalah $=7$

Tabel 4.15 Tingkat aksi yang diperlukan berdasarkan Grand skor

\begin{tabular}{|c|l|}
\hline Level & \multicolumn{1}{|c|}{ Tingkat Aksi dari RULA } \\
\hline 1 & $\begin{array}{l}\text { Apabila grand skor adalah 1 atau 2, tidak ada masalah dengan } \\
\text { postur tubuh selama bekerja }\end{array}$ \\
\hline 2 & $\begin{array}{l}\text { Apabila grand skor adalah 3 atau 4, diperlukan investigasi } \\
\text { lebih lanjut, mungkin diperlukan adanya perubahan untuk } \\
\text { perbaikan sikap kerja. }\end{array}$ \\
\hline 3 & $\begin{array}{l}\text { Apabila grand skor adalah 5 atau 6, diperlukan adanya } \\
\text { investigasi dan perbaikan segea. }\end{array}$ \\
\hline 4 & $\begin{array}{l}\text { Apabila grand skor adalah 7+, diperlukan adanya investigasi } \\
\text { dan perbaikan secepat mungkin. }\end{array}$ \\
\hline
\end{tabular}

Gambar 4.4 Kegiatan Membawa Barang

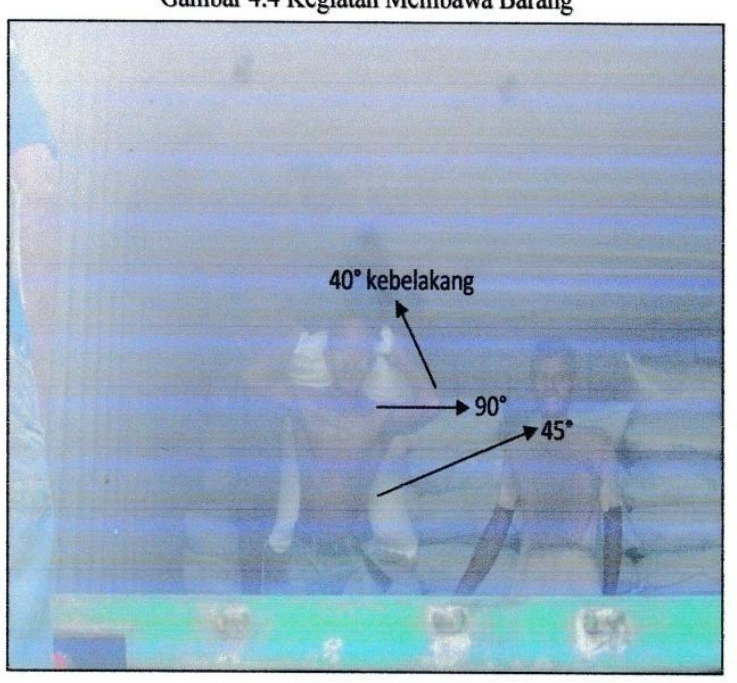

Tabel 4.16 Skor Grup A Kegiatan Membawa Barang

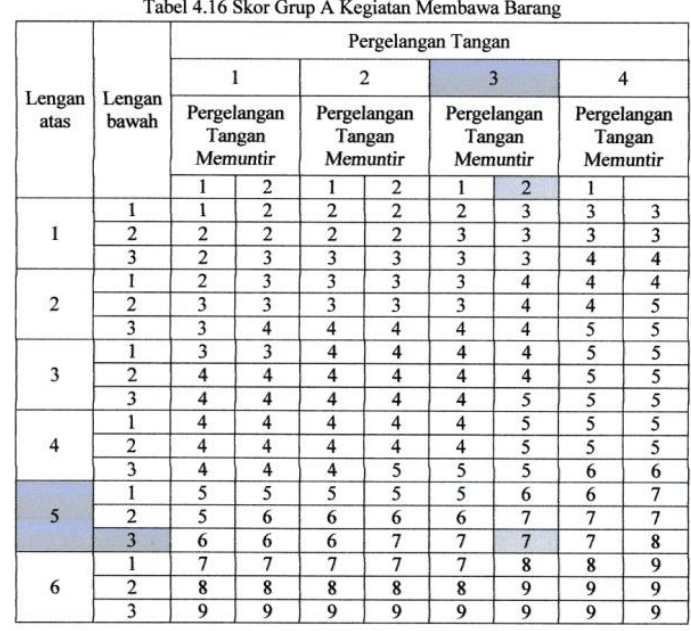

Tabel 4.17 Skor Grup B Kegiatan Membawa Barang

\begin{tabular}{|c|c|c|c|c|c|c|c|c|c|c|c|c|}
\hline \multirow{4}{*}{ Leher } & \multicolumn{12}{|c|}{ Badan (Trunk) } \\
\hline & \multirow{2}{*}{\multicolumn{2}{|c|}{$\begin{array}{c}1 \\
\text { Kaki }\end{array}$}} & \multirow{2}{*}{\multicolumn{2}{|c|}{$\begin{array}{c}2 \\
\text { Kaki }\end{array}$}} & & & & & & & & \\
\hline & & & & & \multicolumn{2}{|c|}{ Kaki } & \multicolumn{2}{|c|}{ Kaki } & \multicolumn{2}{|c|}{ Kaki } & \multicolumn{2}{|c|}{ Kaki } \\
\hline & 1 & 2 & 1 & 2 & 1 & 2 & 1 & 2 & 1 & 2 & 1 & 2 \\
\hline 1 & 1 & 3 & 2 & 3 & 3 & 4 & 5 & 5 & 6 & 6 & 7 & 7 \\
\hline 2 & 2 & 3 & 2 & 3 & 4 & 5 & 5 & 5 & 6 & 7 & 7 & 7 \\
\hline 3 & 3 & 3 & 2 & 4 & 4 & 5 & 5 & 6 & 6 & 7 & 7 & 7 \\
\hline 4 & 5 & 5 & 5 & 6 & 6 & 7 & 7 & 7 & 7 & 7 & 8 & 8 \\
\hline 5 & 7 & 7 & 7 & 7 & 7 & 7 & 8 & 8 & 8 & 8 & 8 & 8 \\
\hline 6 & 8 & 8 & 8 & 8 & 8 & 8 & 8 & 9 & 9 & 9 & 9 & 9 \\
\hline
\end{tabular}

1. Skor aktifitas

Tabel 4.18 Total skor group A dan B Kegiatan Membawa Barang
\begin{tabular}{|c|c|c|c|c|c|c|c|}
\hline \multirow{2}{*}{ Grup A } & \multicolumn{7}{|c|}{ Grup B } \\
\cline { 2 - 8 } & 1 & 2 & 3 & 4 & 5 & 6 & $7+$ \\
\hline 1 & 1 & 2 & 3 & 3 & 4 & 5 & 5 \\
\hline 2 & 2 & 2 & 3 & 4 & 4 & 5 & 5 \\
\hline 3 & 3 & 3 & 3 & 4 & 4 & 5 & 6 \\
\hline 4 & 3 & 3 & 3 & 4 & 5 & 6 & 6 \\
\hline 5 & 4 & 4 & 4 & 5 & 6 & 7 & 7 \\
\hline 6 & 4 & 4 & 5 & 6 & 6 & 7 & 7 \\
\hline 7 & 5 & 5 & 6 & 6 & 7 & 7 & 7 \\
\hline $8+$ & 5 & 5 & 6 & 7 & 7 & 7 & 7 \\
\hline
\end{tabular}

Total skor akhir pengangkatan beras adalah $=7$ 
Tabel 4.19 Tingkat aksi yang diperlukan berdasarkan Grand skor

\begin{tabular}{|c|l|}
\hline Level & \multicolumn{1}{|c|}{ Tingkat Aksi dari RULA } \\
\hline 1 & $\begin{array}{l}\text { Apabila grand skor adalah 1 atau 2, tidak ada masalah dengan } \\
\text { postur tubuh selama bekerja }\end{array}$ \\
\hline 2 & $\begin{array}{l}\text { Apabila grand skor adalah 3 atau 4, diperlukan investigasi } \\
\text { lebih lanjut, mungkin diperlukan adanya perubahan untuk } \\
\text { perbaikan sikap kerja. }\end{array}$ \\
\hline 3 & $\begin{array}{l}\text { Apabila grand skor adalah 5 atau 6, diperlukan adanya } \\
\text { investigasi dan perbaikan segea. }\end{array}$ \\
\hline 4 & $\begin{array}{l}\text { Apabila grand skor adalah 7+, diperlukan adanya investigasi } \\
\text { dan perbaikan secepat mungkin. }\end{array}$ \\
\hline
\end{tabular}

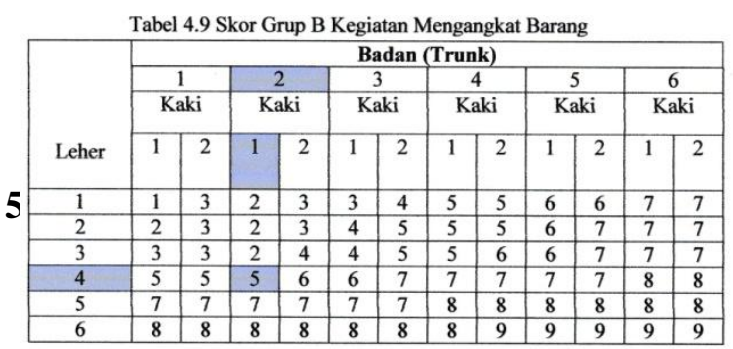

3. Skor aktifitas

Aktifitas dilakukan tidak berulang - ulang dan beban $>10 \mathrm{~kg}$ dengan skor $=3$

4. Total skor group B adalah $5+3=8$

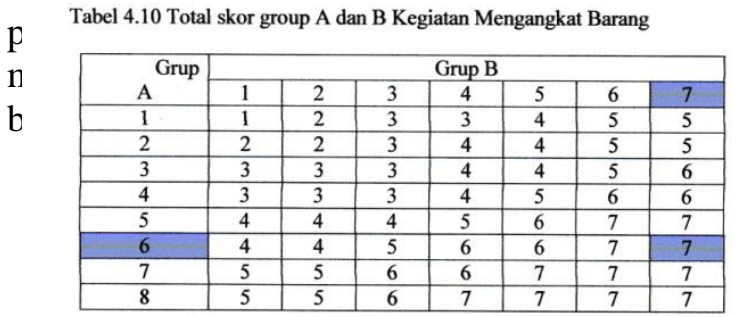

Skor akhir untuk aktifitas mengangkat karton rokok adalah $=7$ I yally verall vallwa pekerjaall yally mereka lakukan sangat berat dan beresikodan diperlukan adanya investigasi dalam perbaikan secepat mungkin.

b. Berdasarkan pengamatan dan wawancara yang dilakukan terhadap operator, terdapat beberapa mengalami keluhan otot. Keluhan yang sering dirasakan adalah keluhan pada otot bagian punggung, bahu, lengan, tangan dan pinggang.

\section{Saran}

a. Hasil Penelitian ini dapat digunakan sebagai bahan panduan untuk melakukan perbaikan postur tubuh pada saat bekerja sehingga mengurangi level resiko pada operator. b. Diharapkan agar para pengelola TKBM maupun pengurus pada kantor PELINDO untuk lebih memperhatikan kondisi kerja para Tenaga kerja demi kenyamanan, kesehatan, keselamatan para tenaga kerja.

c. Berdasarkan hasil pengolahan data dengan metode RULA maka dapat disimpulkan bahwa postur tubuh para operator dibagian pemindahan barang diperlukan tindakan perbaikan seperti menyiapkan alat bantu untuk meringankan pekerjaan para karyawan

d. Melakukan penelitian lanjutan tentang postur kerja dengan menggunakan metode REBA.

\section{DAFTAR PUSTAKA}

Masniar, ST.,MM, Hand Out Analisis Perancangan Kerja II, Sorong 2014

Masniar, ST., MM, Hand Out Ergonomi, Sorong 2015

Tarwaka, PGDip.Sc.,M.Erg, Dasar-dasar Pengetahuan Ergonomi dan Aplikasi di Tempat Kerja, Solo 2010

Sugyono, Metode Penelitian Kuantitatif Kualitatif R\&B, Alfabeta, Bandung 2012

Nurmianto Eko, Ergonomi, Konsep dasar dan Aplikasinya, Prima Printing, Surabaya 1996

Yassierli, P.Dh, Ergonomi Suatu Pengantar, PT. Remaja Rosdakarya, Bandung 2014

Kuswana Sunary Wowo, M.Pd, Ergonomi dan K3, PT. Remaja Rosdakarya, Bandung 


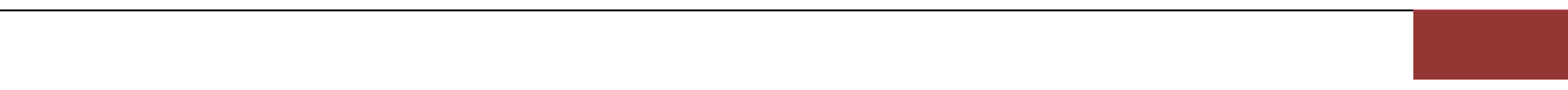

